\title{
PAX1 Gene
}

National Cancer Institute

\section{Source}

National Cancer Institute. PAX1 Gene. NCI Thesaurus. Code C106274.

This gene is involved in both skeletal development and T-cell differentiation. 